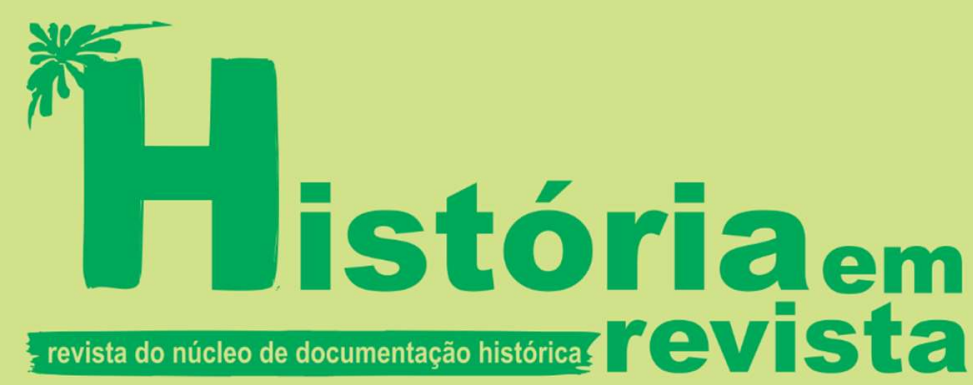

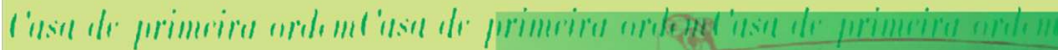

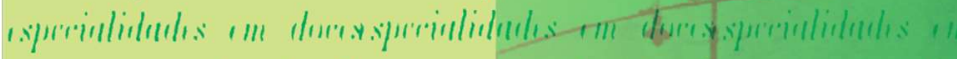

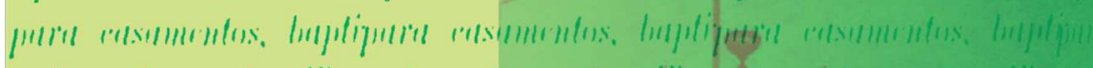

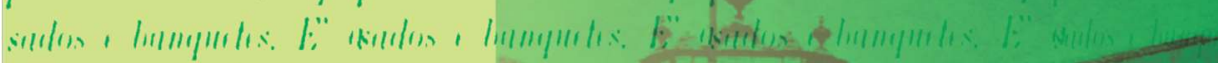

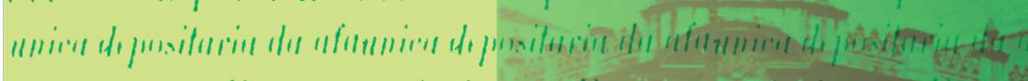

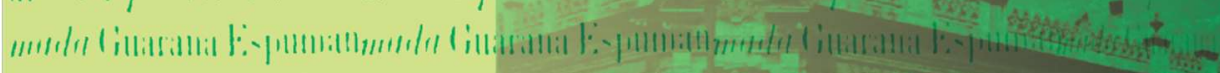

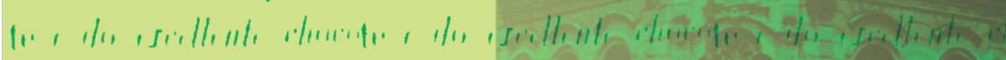

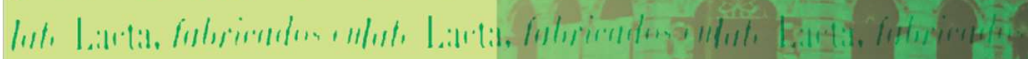

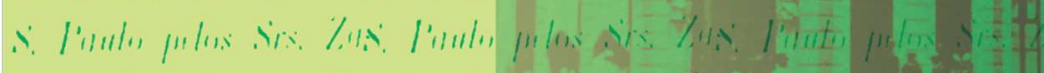

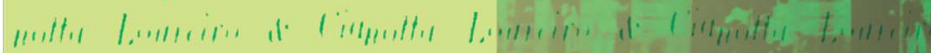

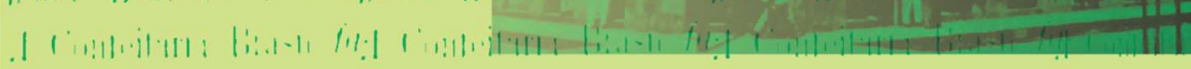




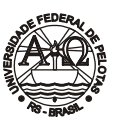

Obra publicada pela Universidade Federal de Pelotas Reitor: Pedro Rodrigues Curi Hallal Vice-Reitor: Luis Isaías Centeno do Amaral

Chefe de Gabinete: Aline Elias Lamas

Pró-Reitor de Graduação: Maria de Fátima Cóssio

Pró-Reitor de Pesquisa e Pós-Graduação: Flávio Fernando Demarco

Pró-Reitor de Extensão e Cultura: Francisca Ferreira Michelon

Pró-Reitor de Planejamento e Desenvolvimento: Otávio Martins Peres

Pró-Reitor Administrativo: Ricardo Hartlebem Peter

Pró-Reitor de Infra-estrutura: Julio Carlos Balzano de Mattos

Pró-Reitor de Assuntos Estudantis: Mário Renato de Azevedo Jr.

Pró-Reitor de Gestão Pessoas: Sérgio Batista Christino

\section{CONSELHO EDITORLAL}

Representante das Ciências Agronômicas: Guilherme Albuquerque de Oliveira Cavalcanti (Titular), Cesar Valmor Rombaldi (suplente) e Fabrício de Vargas Arigony Braga (suplente) | Representantes da Área das Ciências Exatas e da Terra: Adelir José Strieder (titular) e Juliana Pertille da Silva (suplente) | Representante da Área das Ciências Biológicas: Raquel Ludke (suplente) | Representante da Área das Engenharias e Computação: Darci Alberto Gatto | Representantes da Área das Ciências da Saúde: Claiton Leoneti Lencina (titular) e Giovanni Felipe Ernst Frizzo (suplente) | Representante da Área das Ciências Sociais Aplicadas: Célia Helena Castro Gonsales | Representante da Área das Ciências Humanas: Charles Pereira Pennaforte e Guilherme Camargo Massaú (suplente) | Representantes da Área das Linguagens e Artes: Josias Pereira da Silva (titular) e Maristani Polidori Zamperetti (suplente)

\section{INSTITUTO DE CIÊNCLAS HUMANAS}

Diretor: Prof. Dr. Sidney Gonçalves Vieira

Vice-Diretor: Prof. Dr. Sebastião Peres

\section{NÚCLEO DE DOCUMENTACÃO HISTÓRICA}

Coordenadora:

Prof ${ }^{a}$ Dra. Lorena Almeida Gill

Membros do NDH:

Prof ${ }^{a}$ Dra. Beatriz Ana Loner

Prof ${ }^{a}$ Dra. Lorena Almeida Gill

Prof. Dr. Paulo Ricardo Pezat

Prof. Dr. Aristeu Elisandro Machado Lopes

Técnico Administrativo:

Paulo Luiz Crizel Koschier

HISTÓRIA EM REVISTA - Publicação do Núcleo de Documentação Histórica

Comissão Editorial:

Prof. Dr. Aristeu Elisandro Machado Lopes

Prof ${ }^{a}$ Dra. Beatriz Ana Loner

Prof ${ }^{a}$ Dra. Lorena Almeida Gill

Prof. Dr. Paulo Ricardo Pezat

Conselho Editorial:

Prof ${ }^{a}$ Dra. Helga I. Landgraf Piccolo (UFRGS)

Prof. Dr. René Gertz (UFRGS) (PUCRS)

Prof. Ms. Mario Osorio Magalhães (UFPel)

Prof. Dr. Temístocles A. C. Cezar (UFRGS)

Profa. Dra. Beatriz Teixeira Weber (UFSM)

Prof ${ }^{a}$. Dra. Maria Cecília V. e Cruz (UFBA)

Prof. Dr. Marcelo Badaró Mattos (UFF)

Profa. Dra. Joan Bak (Univ. Richmond - USA)

Prof. PhD Pablo Alejandro Pozzi (Universidad de Buenos Aires).

Prof. Tommaso Detti (Università Degli Studi di Siena)

Editor: Prof. Dr. Aristeu Elisandro Machado Lopes

Editoração e Capa: Paulo Luiz Crizel Koschier

Editora e Gráfica Universitária

R Lobo da Costa, 447 - Pelotas, RS - CEP 96010-150 |

Fone/fax: (53) 32278411

e-mail: editora@ufpel.edu.br

\section{Impresso no Brasil}

Edicão: 2017

ISSN - 1516-2095

Dados de catalogação na fonte: Aydê Andrade de Oliveira - CRB - 10/864

História em revista / publicação do Núcleo de Documentação Histórica. Instituto de Ciências Humanas. Universidade Federal de Pelotas. v.23, (dez. 2017). - Pelotas: Editora da UFPel, 2017.

$1 \mathrm{v}$.

Anual

ISSN 1516-2095

1. História - Periódicos. I. Núcleo de Documentação Histórica. Instituto de Ciências Humanas. Universidade Federal de Pelotas. CDD 930.005

\section{Indexada pela base de dados Worldcat Online Computer Library Center}

\section{PEDE-SE PERMUTA} WE ASK FOR EXCHANGE

UFPel/NDH/Instituto de Ciências Humanas

Rua Cel. Alberto Rosa, 154

Pelotas/RS - CEP: 96010-770

Caixa Postal 354

Fone: (53) 32843208

\section{http://wp.ufpel.edu.br/ndh/} e-mail:ndh.ufpel@gmail.com 


\title{
LITERATURA, HISTÓRIA E REPRESENTAÇÃO DO PASSADO EM ANATOLE FranCE
}

\author{
LITERATURA, HISTORY AND REPRESENTATION OF THE PAST IN ANATOLE \\ FRANCE
}

\begin{abstract}
Alanna de Jesus Teixeira ${ }^{1}$
Resumo: O objetivo deste trabalho é problematizar a representação do passado na obra Les dieux ont soif (Os deuses têm sede, 1912) do escritor francês Anatole France (1844-1924). O passado que não é apenas o da história da Revolução Francesa e do período do "Terror" que o romance aborda, mas que combina o presente do autor, sua trajetória e o contexto sociocultural e político do início do século XX. O romance demonstra notável capacidade de representação histórica sobre o período que procura retratar, além de suscitar uma discussão a respeito do tempo, elemento chave de sua construção.
\end{abstract}

Palavras-chave: Anatole France. Revolução Francesa. Romance histórico. Representação do passado.

I.

O objetivo deste trabalho é problematizar a representação do passado na obra Les dieux ont soif (Os deuses têm sede, 1912) do escritor francês Anatole France (1844-1924). O passado que não é apenas o da história da Revolução Francesa e do período do "Terror" que o romance aborda, mas que combina o presente do autor, sua trajetória e o contexto sociocultural e político do início do século XX.

O romance demonstra notável capacidade de representação histórica sobre o período que procura retratar, além de suscitar uma discussão a respeito do tempo, elemento chave de sua construção. É possível perceber a criação de trajetórias aceleradas (como do protagonista Évariste Gamelin) que fazem parte de um fenômeno maior que foi encarnado pela Revolução Francesa: a própria modernidade.

Como base para este estudo, levamos em consideração os debates sobre as relações entre literatura e história, e os conceitos de romance histórico, ficção e mímesis; entendendo que a literatura é capaz de produzir e vincular conhecimento sobre o mundo, permitindo um acesso voltado a zonas obscuras da história e proporcionando uma inteligibilidade à experiência

1 Mestranda em História (Programa de Pós-Graduação em História - UFRGS). Contato: alanna.teixeira@ufrgs.br.

História em Revista, Pelotas, 108-126, v. 23, dez:/2017 
humana. Ademais, o contexto do autor, sua atuação política, e as questões discutidas no período de elaboração da obra sobre a Revolução Francesa em função de sua herança para a Terceira República também são levantadas como elementos do passado que engendraram a obra.

Dessa forma, entendemos que História e Literatura não disputam a primazia de representação da realidade e não se confundem. Mantêm diferentes recursos e liberdades e podem trabalhar conjuntamente em benefício do conhecimento que temos acerca do passado e de nosso próprio presente.

II.

Ao pensar a representação do passado que a obra configura, a experiência temporal aparece como um elemento chave para compreender essa representação. Falamos de uma experiência temporal que exprime uma nova forma de se relacionar com o tempo, de vivenciá-lo, demarcando uma nova experiência, característica dos "novos tempos", do tempo revolucionário, que significa, em última instância, a modernidade. Essa nova experiência está engendrada a uma aceleração do tempo, ou seja, uma alteração da velocidade com a rapidez da sua passagem. A Revolução traz consigo um sentimento de mudança e aceleração muito fortes: são os novos tempos que mudam o regime, os políticos, o calendário, os valores, os costumes, e com isso, a própria forma de encarar o tempo. Os anos dominados pelo Terror (17931794), são a marca distintiva desta nova experiência, radicalizada durante aproximadamente um único ano. Um ano que Les dieux ont soif apresentará Évariste Gamelin - personagem principal do enredo - como pintor frustrado, enamorado, jurado do Tribunal Revolucionário, algoz de sua família e amigos, e finalmente, sua queda e fim, tal como aqueles a quem condenara. O presente se dilui, pois o futuro agora representa o principal tempo, aquele que deveria ser cultivado, através do presente.

A obra oferece uma oportunidade de reflexão em torno do período histórico do qual trata, e de como o autor mobiliza essa experiência do passado, evidenciando uma atitude eminentemente política e que está relacionada com o contexto imediatamente anterior à Primeira Guerra Mundial.

A história combina personagens de extração histórica (Robespierre, Marat, Danton, Saint-Just, Brissot) e imaginados, embora representativos de um grupo social ou classe em conflito (nobreza, clero, profissionais liberais, 
povo/trabalhadores). O cenário: a Paris revolucionária e em constante ebulição, que expôs constantemente os símbolos dos novos e velhos tempos, apontando rupturas e continuidades. A obra retoma com bastante detalhamento esse momento específico da Revolução Francesa, que é dominada pela ala jacobina da Convenção Nacional (junho/1793 a julho/1794) após a queda da Gironda.

Les dieux ont soif foi publicado pela editora Calmann-Lévy2, e marcou uma nova fase na carreira de Anatole France. O que fez o mestre descer de sua "torre de marfim" foi o conturbado Affaire Dreyfus (1894-1906), que dividiu intelectuais e políticos e repercutiu internacionalmente. France posicionou-se a favor do capitão judeu do exército francês Alfred Dreyfus e ficou ao lado do escritor Émile Zola quando este escrevera o incendiário J'accuse, tornando-se um dos mais importantes dreyfusards.

É preciso também levar em consideração que era um momento delicado para a Europa como um todo. As posições políticas radicalizavam-se cada vez mais e a eminência de uma guerra pairava no ar. France não ficou indiferente, por isso a radicalização de suas posições, inclusive durante a guerra. No entanto, suas oscilações podem ser encaradas como contradições próprias do escritor, mas que fundamentalmente estavam de acordo com os seus mais profundos ideais humanistas. France jamais abandonou seu ceticismo, mesmo quanto ao socialismo e a Revolução Russa, a democracia e a liberdade. Mais cedo ou mais tarde, retirou-se da cena política propriamente dita, para dedicar-se apenas à literatura.

Algumas de suas obras seguiram com um tom mais engajado, sem deixar de se aproximar de sua vida pessoal e de temas universais sobre a condição humana. Contudo, o lançamento de Les dieux ont soif faz parte desse contexto específico em que a Terceira República francesa impunha-se e com ela uma reabilitação da ideia de Revolução Francesa. O romance sobre o Terror suscitou certo desapontamento e irritação entre os seus pares, consternados com uma visão tão claramente antijacobina por parte de um notável anticlerical como France.

III.

Les dieux ont soif é particularmente interessante por sua dimensão

\footnotetext{
2 Neste trabalho utilizamos uma edição brasileira (FRANCE, 2007) para as citações em português. Para consulta, utilizamos uma edição francesa (FRANCE, 1989).
} 
histórica, e podemos perceber que o tempo é a base para a construção da estrutura narrativa. Por outro lado, mais um ponto deve ser levado em consideração: a literatura lida com a realidade e é a partir dela que elabora sua criação, estabelecendo, portanto, um tipo de conhecimento sobre ela, que é inteiramente legítimo. Como qualquer outro conhecimento, possui características e limitações próprias, e não abarca (nem pretende) a totalidade da realidade. Imediatamente lembramos da própria História e suas particulares limitações3.

O romance histórico, gênero híbrido, além de possuir a estrutura de um romance, demonstra vocação para lidar com temas históricos e atingir o grande público. Os escritores desse gênero geralmente têm tomado para si a tarefa de interpretar e reinventar (não no sentido de mentir) determinado fato ou conjunto de acontecimentos de grande relevância em determinada sociedade, mesclando personagens históricos e imaginados, e criando cenários e personagens tão vivos e verossímeis que podemos muitas vezes jurar aprender muito mais sobre a época recriada na obra literária do que nos trabalhos dos historiadores de profissão. Os romances históricos surgidos a partir de Walter Scott, e que tiveram seu ápice no período romântico, são uma prova disso.

Esse modelo de romance histórico criado por Scott no início do Oitocentos - baseado nos romances realista do século XVIII - está associado ao contexto em que vivia a Europa pós-Revolução Francesa. A consciência histórica que se tornou parte da vida do homem mais comum o aproximou do destino que sua pátria, deixando clara essa nova experiência de historicidade:

Le XIXe siècle, siècle de l'histoire comme du roman, a ainsi vu s'imposer cette double évidence: celle de l'histoire, conçue comme processus, portée par un temps acteur, et se vivant sur le mode de l'accélération; celle du roman, appelé à dire ce monde nouveau (HARTOG, 2013, p. 165).

György Lukács, importante teórico sobre o romance histórico, demonstra em sua obra clássica $\mathrm{O}$ Romance Histórico4 as condições específicas em que este gênero foi gerado, e aponta suas principais características: "amplo retrato dos costumes e das circunstâncias dos acontecimentos, o caráter dramático da ação e, em estreita relação com isso, o

3 "Peut-être l'histoire est-elle comme un roman, mais, surtout, seul le roman est à même d'approcher la réalité de l'Histoire, car, par son attention aux détails, aux incertitudes, à l'aléatoire, il peut finalement produire un analogue de son inépuisable complexité" (HARTOG, 2013, p. 178).

${ }^{4}$ LUKÁCS, 2011. A obra foi originalmente publicada em 1937. 
novo e importante papel do diálogo no romance" (LUKÁCS, 2011, p. 47). Recorrendo a criação de um herói mediano (correto, mas nunca heroico), Scott "se esforça para figurar as lutas e as oposições da história por meio de homens que, em sua psicologia e em seu talento, permanecem sempre como representantes de correntes sociais e potências políticas" (LUKÁCS, 2011, p. 50). Sua verdadeira grandeza está
em dar vida humana a tipos sociais históricos. Antes de Scott, os traços humanos típicos, em que se evidenciam as grandes correntes históricas, jamais haviam sido figurados com tal grandiosidade, univocidade e concisão. E, acima de tudo, jamais essa tendência da figuração havia sido trazida conscientemente para o centro da representação da realidade (LUKÁCS, 2011, p. 51).

O grande sucesso do romance histórico está associado ao seu desenvolvimento como principal gênero no contexto do Romantismo período histórico de formação dos Estados Nacionais. A literatura romântica estava em busca das raízes de cada nação e para isso necessariamente se voltava para o passado, e a grande produção de romances históricos até o final do século é resultado disso. O período que me proponho a estudar, sendo imediatamente posterior - mas não totalmente desvinculado - demonstra uma nova fase da literatura com o surgimento de novas tendências literárias, como o simbolismo, e mais adiante, as escolas modernistas, que trariam novos elementos para o campo da arte. Nesse fin-de-siècle, o romance histórico já não era o gênero por excelência, embora eventualmente resgatado por literatos que buscavam atingir determinados objetivos através do uso deste formato de literatura.

Para realizar este trabalho, combinei a análise da obra Les dieux ont soif, em particular, a uma leitura do contexto em que foi produzida. A intenção não foi apreciar os seus parâmetros linguísticos - questão abordada por críticos literários - mas realizar uma análise historiográfica que identifique a representação do passado na obra, por meio de estratégias que estabeleçam um diálogo entre o texto e seu mundo circundante. Apenas a releitura atenta e crítica puderam contribuir para o objetivo do trabalho, que busca ir além da leitura distraída do leitor comum.

A seguir serão retomadas algumas ideias-chave para compreender a representação do passado na obra, como ficção, literatura e romance histórico, a partir das formulações apontadas por Luiz Costa Lima, Paul Ricoeur e Fredric Jameson. Em seguida, será feita a análise de Les dieux ont soif, retomando os argumentos históricos que possibilitam explorar o romance de forma mais apurada. 


\section{$* * *$}

Provocando discussões que datam do início da literatura ocidental, as relações entre literatura e história dividem e aproximam pensadores dentro de diversas áreas de estudo. Quais os limites que separam uma escrita da outra, onde literato ou poeta e historiador se aproximam e distanciam, como representam a realidade, onde está a ficção em seus discursos, são algumas questões debatidas sob diversos ângulos - como no caso da epopeia homérica, Ilíada e Odisséia, em que "a matéria narrada combinava uma substância mítica, que carregava consigo o dado maravilhoso, e tinha, para os antigos, o valor de história e o investimento literário da poesia" (BASTOS, 2007, p. 9), a questão já estava dada. O debate adquire contornos mais preciso no século XIX momento de afirmação dos diversos campos científicos - em que história e literatura também procuram delimitar suas áreas de conhecimento, suprimindo aquilo que as aproximava, com o propósito de institucionalização. No caso da história, esse expurgo significou eliminar os traços fictícios ou retóricos de seu discurso, o tornando o mais objetivo possível na apreensão da realidade, ao mesmo tempo em que trouxe para si o monopólio da explicação da realidade histórica, ou seja, da verdade.

Organizadas como campos autônomos, história e literatura mantiveram suas fronteiras através de uma aceitação que "repousou, por anos, na anuência surda, baseada no princípio puro e simples de que ambas formavam gêneros diferentes, ainda que afins à mesma espécie, as chamadas "humanidades" (AGUIAR, 1997, p. 271). Contudo, o curso da história enquanto disciplina traria novamente esse debate à tona - embora nunca tenha desaparecido questionando principalmente sua pretensa objetividade e capacidade de apreensão da realidade, ou seja, seu caráter científico. No que diz respeito às fronteiras com a literatura, a principal discussão retoma o caráter narrativo do discurso historiográfico e sua proximidade com a narrativa literária ou ficcional, uma vez que utilizaria os mesmos recursos que um literato na produção de sua narrativa. Na perspectiva do balanço elaborado por Barros a respeito dessa discussão, o autor pondera que devemos

assimilar esta 'consciência da narratividade' sem sacrificar os patamares que permitem relacionar a História não meramente a uma ficção, mas a materiais historicamente circunstanciados e que fornecem efetivamente uma base ao historiador e ao leitor de história que podem trazer ao texto historiográfico a legitimidade, se não de uma ciência (o que não está descartado), ao menos de uma prática cientificamente conduzida (BARROS, 2010, p. 14). 
Ao pensar nas fronteiras entre história e literatura, temos necessariamente de abordar o conceito de ficção. Essa reflexão é necessária porque associamos imediatamente o termo à literatura, com conotação de mentira ou inverdade. Luiz Costa Lima, importante teórico das relações entre literatura, história e ficção, aponta que

embora o latim clássico reconhecesse no termo 'fictio' a dupla acepção até hoje encontrada nas línguas que dele derivavam, fictio significando tanto 'invenção, criação', como 'mentira, fraude', na verdade a primeira e positiva acepção não [foi] desenvolvida (COSTA LIMA, 2008, p. 167).

O conceito de ficção está associado não apenas à ficção literária, mas a diferentes "ficções" cotidianas com as quais lidamos, e que são necessárias ao convívio dos homens em sociedade - como a ideia de poder e de liberdade que, por não se justificarem naturalmente, precisam se fazer convencer para persistirem. Essas "ficções cotidianas são do interesse, em princípio, de todos aqueles que têm um cotidiano a preservar" e por isso não são discutidas como invenções. Já a ficção literária, ao contrário, "tende a se pôr em questão, a desnudar-se a si mesma, i.e., a declarar-se ficção" (COSTA LIMA, 2008, p. 174). Sendo assim, é preciso deixar claro a distinção entre ficção e mentira:

a ficção não trabalha a priori com a idéia de verdade. A ficção se cruza com a verdade à medida que ela, ficção, se cruza com o mundo, porque, do contrário, seria uma grande paranóia ou uma grande fantasia (COSTA LIMA, 2008, p. 174).

Já a mentira, "pertence a um campo bem pragmático: o mentiroso sabe o que faz, conhece a verdade que nega; decide-se por ela" (COSTA LIMA, 2008, p. 174).

O mundo da ficção é um mundo do faz-de-conta, ainda que sério. Essa seriedade faz com que ela se cruze, em seu caminho, com a verdade e/ou que se desnude a si mesma, que se declare ficção. A verdade da ficção é o desnudamento, é o apresentar-se como ficção, o mostrar-se como ficção. [...] O que significa dizer: a ficção tem a vocação crítica de mostrar aquilo que estava nos seduzindo. Isso, porém, não a torna verdade; mas nos diz que ela é o meio humano para que, através de um discurso que se auto-apresenta como nãoverdade, apreenda-se a verdade (COSTA LIMA, 2008, p. 175).

No caso do historiador, a verdade buscada é o que caracteriza a aporia da história - diferentemente do discurso ficcional, que não postula uma verdade, mas a põe em parênteses (COSTA LIMA, 2006, p. 21). Ambos os discursos, à sua maneira, têm a capacidade para representar a realidade. A literatura, no entanto, possui recursos e uma liberdade diferente daquela do 
historiador, e por isso, a sua representação parecerá por vezes mais colorida e vivaz:

a literatura é capaz de algo que comumente é negado ao historiador: quando, pelas suas qualidades, um autor consegue criar "vida" em personagens que estão compostos numa determinada conjuntura e numa sociedade específica, muitas vezes ela - antes mesmo que a história - pode ser mais reveladora daquela verdade buscada (GUAZZELLI, 2009, p. 371).

História e literatura lidam com elementos em sua composição que as afastam e aproximam. A imaginação, presente nos dois discursos, ocupa posições diferentes. "A imaginação atua na escrita da história, mas não é o seu lastro. Porosa, a história não há de ser menos veraz" (COSTA LIMA, 2006, p. 65). Neste caso, ela está a serviço do entendimento.

A literatura, pensada em sua heterogeneidade constitutiva, engloba obras de caráter ficcional e não-ficcional, por exemplo, romances e biografias, respectivamente. Portanto, "o estatuto do ficcional não abrange toda a gama de gêneros poéticos e literários" (COSTA LIMA, 2006, p. 348), ou seja, há obras que podem ser consideradas literárias, mas que não tem como base a ficção, por exemplo: biografias, ensaios, diários.

Outro conceito abordado por vários teóricos e que pode auxiliar, neste trabalho, a pensar literatura e história, é a mímesis. Através desta se "estabelece uma correspondência entre um estado de mundo e uma configuração textual" (COSTA LIMA, 2006, 188). A mímesis inevitavelmente perpassa a escrita da história, na medida em que essa se afasta da elaboração conceitual:

embora a mímesis se mostre na atividade historiográfica, em decorrência de o seu agente sentir, reagir e pensar o mundo, a partir do lugar que nele ocupa, essa resposta ao mundo é menos uma mímesis como princípio de construção do que como inevitabilidade; uma mímesis por decorrência da cena da enunciação, tanto mais viva quanto menos a atividade historiográfica dispõe de conceitos. Pois há uma relação direta entre a configuração da mímesis e a ausência ou insuficiência de conceitos (COSTA LIMA, 2006, p. 155).5

Podemos explorar os limites entre literatura e história por meio do romance, tanto pelo conteúdo histórico que carrega, quanto por sua própria

5 Mais à frente, o autor observa que é "por meio da mímesis [que] o texto acolhe, seleciona e transforma as configurações sociais. A sociedade é sua parceira porque é na sociedade que circulam valores, usos e costumes, constituindo uma lógica social, que como ainda dizia Gabriel Tarde, anterior à lógica do indivíduo. A mímesis ancora a obra no mundo. [...] Quando mais um discurso encaminha para a formulação de conceitos ou tem os seus pontos capitais ocupados por conceitos, tanto menos a obra pertencerá ao campo da mímesis. Se a vocação do conceito é a uniformização do particular, a mímesis atua em sentido contrário. Por ela, o particular se pluraliza por dentro" (COSTA LIMA, 2006, p. 207). 
formação enquanto gênero literário. Neste momento, interessa sobretudo a capacidade de representação da realidade através do romance, já que este "deve sua qualidade de gênero literário não a seu caráter documental - o que o limitaria a elemento para a História - nem à linguagem refinada [...], mas à sua força de ficção. [...] pelo romance, a literatura é o discurso ficcional por excelência da modernidade" (COSTA LIMA, 2006, p. 340).

O fato de o romance ter de se afirmar num quadro teórico no qual as posições
já estavam marcadas, com abundante conceituação dos gêneros literários e suas
respectivas modalidades, levou-o, segundo estudiosos, a contrair alianças com
formas discursivas que lhe abonassem a seriedade, evitando ser confundido com
o fanatismo delirante do velho romance de origem medieval. Dentre essas
formas discursivas, a que lhe estaria mais próxima era a história (BASTOS, 2007,
p. 10).

Apesar disso, o leitor de um romance não o confunde com a leitura de um livro de história. O pacto entre autor e leitor do romance permite que este "prepare-se para entrar num universo irreal a respeito do qual a questão de saber onde e quando aquelas coisas aconteceram é incongruente", desta forma, "o leitor suspende de bom grado sua desconfiança, sua incredulidade, e aceita entrar no jogo do como se - como se aquelas coisas narradas tivessem acontecido" (RICOEUR, 2007, p. 274-275).

Esse pacto não se altera no caso específico do romance histórico - que pode ser entendido como um subgênero do romance. Trata-se de um tipo de literatura que "procurou uma veracidade que, se não substituía a história como ciência, tinha muito apelo: o "romance histórico", de grande difusão no século XIX, com um papel protagonista na difusão de uma ideologia marcante, o nacionalismo" (GUAZZELLI, 2009, p. 371). O surgimento desse gênero foi possível porque a concepção de história havia se transformado: "avec la Révolution, la conception de l'Histoire change, et le roman va se nourrir de cette évolution, pour trouver une nouvelle forme, explicitement historique. Au XIXe siècle, le véritable roman historique peut naitre (GENGEMBRE, 2010, p. 367).

A difusão do romance histórico fez parte do nacionalismo nascente em boa parte do Ocidente - e nas próprias obras - dentro dos parâmetros do Romantismo. No entanto, "se o romance histórico começa como um exercício de construção nacional no rescaldo da reação romântica à Revolução Francesa e à expansão napoleônica, os resultados variam segundo cada contexto" (ANDERSON, 2007, p. 211). O caso francês será paradigmático, embora os primeiros romances históricos tenham nascido da tradição scottiana.

O romance histórico se distingue dos outros tipos de romances ou 
histórias romanceadas por alguns elementos que lhe são próprios. O crítico Fredric Jameson, a partir da obra de Lukács, estabelece alguns parâmetros para a constituição do gênero:

O romance histórico, portanto, não será a descrição dos costumes e valores de um povo em um determinado momento de sua história (como pensava Manzoni); não será a representação de eventos históricos grandiosos (como quer a visão popular); tampouco será a história das vidas de indivíduos comuns em situações de crises extremas (a visão de Sartre sobre a literatura por via de regra); e seguramente não será a história privada das grandes figuras históricas (que Tolstói discutia com veemência e contra o que argumentava com muita propriedade). Ele pode incluir todos esses aspectos, mas tão-somente sob a condição de que eles tenham sido organizados em uma oposição entre um plano público ou histórico (definido seja por costumes, eventos, crises ou líderes) e um plano existencial ou individual representado por aquela categoria narrativa que chamamos de personagens. Seu centro de gravidade, no entanto, não será constituído por tais personagens, ou por sua psicologia, suas vivências, suas observações, suas alegrias ou seus sofrimentos. Esse plano existencial pode incluir todos ou qualquer um desses aspectos, e o modo de ver do personagem pode variar do convencional ao disperso e pós-estrutural, do individualismo burguês ao descentramento esquizofrênico, do antropomórfico ao mais puramente actancial. A arte do romance histórico não consiste na vívida representação de nenhum desses aspectos em um ou em outro plano, mas antes na habilidade e engenhosidade com que a sua intersecção é configurada e exprimida (JAMESON, 2007, p. 192).

Isso valerá para o romance histórico de tendência romântica ou realista, grosso modo. O romance histórico romântico, que alcançara seu auge em meados do século XIX, perdeu espaço para outras vertentes não engajadas no nacionalismo que surgiram no final do século:

o romance histórico como gênero predominou maciçamente sobre todas as demais formas narrativas até a era eduardiana. Ele combinou um enorme sucesso de mercado com um contínuo prestígio estético. $\mathrm{Na}$ derradeira temporada da Belle Époque, Anatole France publicava Les Dieux Ont Soif, Ford Maddox Ford seu Fifth Queen e até Conrad concluía a sua carreira com um par de ficções históricas, situadas mais uma vez na época napoleônica (ANDERSON, 2007, p. 212-213).

O romance de France faz parte de um realismo tardio que caracterizou o final do século, não partilhando as novas tendências da modernidade. Manifesta as características propostas por Jameson, expondo um plano público/histórico (a experiência histórica dos anos 1793 e 1794, conhecidos como a fase do "Terror" da Revolução Francesa), um plano existencial/individual (através das vivências dos diversos personagens, especialmente Évariste Gamelin), e o entrosamento dessas duas faces, que levam a história do romance para além do período representado. 
No Brasil, o romance histórico, de forma geral, tem sido retomado na historiografia à luz de estudos teóricos mais atualizados (ou antes pouco considerados). É uma temática de grande dificuldade por ser objeto de estudo no campo da literatura, e provocar necessariamente uma discussão teórica acerca do caráter narrativo deste gênero e sua proximidade/distanciamento com a própria escrita da história. Mesmo que diversos autores afirmem que o romance histórico não é seu concorrente, a questão, como foi visto, não pode ser posta de lado, pois toca o próprio fazer historiográfico. Além disso, outros traços parecem aproximar o romance histórico da história - como a pesquisa, o uso de documentos6, o tratamento de temática histórica geralmente de grande relevância para determinada sociedade ou nação - mas nem por isso confundilos:

a história e a ficção só concretizam suas respectivas intencionalidades tomando de empréstimo a intencionalidade da outra. [...] essa concretização só é alcançada na medida em que, por um lado, a história se serve de alguma maneira da ficção para refigurar o tempo, e em que, por outro, a ficção se serve da história com o mesmo intuito (RICOEUR, 2010c, p. 311-312).

Com isso, Paul Ricoeur chama a atenção para a refiguração do tempo, e como este se torna tempo humano através do entrecruzamento da história e da ficção. "Desse entrecruzamento, dessa sobreposição recíproca, dessa troca de lugares, procede o que se convencionou chamar o tempo humano, onde se conjugam a representância do passado pela história e as variações imaginativas da ficção" (RICOEUR, 2010c p. 328).

IV.

As experiências vividas por Évariste Gamelin no romance representam as principais características do período do Terror revolucionário, através da rapidez de sua ascensão, radicalização e queda. A história inicia em maio de $1793 \mathrm{em}$ meio à guerra nas fronteiras contra as potências estrangeiras, o começo da guerra na Vendéia e a criação do Comitê de Salvação Pública. Ao longo de toda a história, o leitor é confrontado com as mudanças e as permanências geradas pela Revolução e o período do Terror. Évariste, antes da

6 “[Há uma] variedade de posições quanto ao aproveitamento das fontes documentais pelos autores de romances históricos [...]. Do respeito reverente às fontes tidas como fidedignas, portanto incontestáveis, à afirmação de orgulhosa independência em relação a elas, passando pela conciliação das duas ordens de exigência, sempre se faz presente o reconhecimento da pesquisa. Isso é decorrência do hibridismo inerente ao romance histórico" (BASTOS, 2012, p.76-77). 
Revolução, era um pintor que seguia os parâmetros artísticos do Antigo Regime, mas que então adere ao novo estilo e se torna discípulo do pintor das causas revolucionárias, Louis David, pintando cenas relacionadas à situação política e aos novos valores revolucionários. Duas fortes convicções acompanharão Évariste até o momento de sua morte: a necessidade de ser implacável com aqueles que estão contra a Revolução (eliminando os que não fazem parte da comunidade de cidadãos e que ameaçam a França) e confiar a salvação da pátria em perigo ao mais virtuoso dos patriotas (num verdadeiro culto à personalidade).

Évariste se torna membro da seção do Pont-Neuf de Paris, do Comitê Militar, Conselho Geral da Comuna e do Clube dos Jacobinos. É preciso lembrar que este período histórico específico da Revolução Francesa sob o domínio do governo revolucionário foi bastante curto, mas responsável por encaminhar as medidas para instauração do Terror. Será no Tribunal Revolucionário, responsável por julgar os crimes contra a Revolução, que Évariste Gamelin exercerá atividade de jurado, participando dos julgamentos que, na maioria dos casos, consideravam os acusados culpados por seus supostos crimes.

A virada à esquerda no ano de 1793, sobretudo após a expulsão dos políticos girondinos da Convenção e a consequente radicalização, mostra que a Revolução parecia mudar completamente o rumo não apenas da nação, mas do cotidiano das pessoas. Os que em 1789 haviam se abraçado em comemoração à vitória dos direitos do homem, em 1793 denunciavam uns aos outros como suspeitos. Assim podemos perceber como as mudanças e a aceleração do tempo ficaram mais e mais presentes no cotidiano da população.

Reinhart Koselleck observa em seu livro Futuro Passado, a transformação na forma de percepção do tempo, particularmente a partir da experiência revolucionária, tomando como exemplo um dos discursos de Robespierre:

a transformação da estrutura temporal, nesse período, é o nosso tema aqui. Em 10 de maio de 1793, em seu famoso discurso sobre a Constituição revolucionária, Robespierre declara: "É chegada a hora de conclamar cada um para seu verdadeiro destino. O progresso da razão humana preparou esta grande Revolução, e vós sois aqueles sobre os quais recai o especial dever de acelerá-la." A providencial fraseologia de Robespierre não é capaz de dissimular que o horizonte de expectativa alterou-se em relação à situação inicial. [...] Para Robespierre, a aceleração do tempo é uma tarefa do homem, que deverá introduzir os tempos da liberdade e da felicidade, o futuro dourado (KOSELLECK, 2006, p. 25). 
Em outro trabalho, investigando a abreviação do tempo, aceleração e secularização e sua afinidade com o surgimento da modernidade, Koselleck (2003) aponta que com o Iluminismo, o futuro deveria necessariamente trazer um tempo de felicidade e liberdade por intermédio da ação humana, que aceleraria esse tempo. Apenas o homem poderia impor essa aceleração, que transforma a sociedade e a liberta de toda a forma de dominação. O caráter inovador da experiência revolucionária francesa é justamente a prática dessa aceleração de forma visível na história, que se tornou a proposição da experiência histórica da modernidade (KOSELLECK, 2003, p. 64).

A tarefa de acelerar o tempo e nele instaurar os tempos da liberdade e da felicidade comunitária será perseguida pelo jovem Évariste que, embevecido dos discursos do Incorruptível, mergulhará nas abstrações aludidas por Robespierre em seus discursos, e demonstrará, através de suas atitudes, um verdadeiro fanatismo por tais princípios. Essa adesão cega àquilo que consideravam como "princípios revolucionários" (na verdade jacobinos), parte também do reconhecimento de que, diferentemente do Antigo Regime - esse tempo da ignorância em que o homem comum, o povo, não passavam de expectadores da história - a Revolução colocara em cena outros personagens, novos homens, e que todos, inclusive Évariste, um pequeno e jovem pintor, poderia interferir em seu curso. Contudo, Évariste deveria afastar-se da humanidade, desviar-se do curso natural de sua própria vida, para construir a história, o futuro. Isso porque participar do processo de ruptura com o Antigo Regime o exigia, era preciso cortar toda a vinculação com aquele passado, e enfrentar todas as oposições e hesitações. A felicidade nasceria no momento em que estes homens revolucionários estivessem, por fim, inscritos no passado.

\section{$* * *$}

Embora em seu primeiro julgamento como jurado, Évariste tenha contribuído para a absolvição do acusado, a partir do segundo julgamento sua conduta se torna mais severa. $\mathrm{O}$ acusado era um general vencido, e todos os fatos envolvidos pareciam obscuros, tornando difícil a tomada de uma decisão. A despeito disso, manifesta-se pela acusação. Julgar um general derrotado ou uma pobre mulher que gritara na rua "Viva o reil" não fazia diferença para o Tribunal. Ambos eram considerados crimes contra a nação, contra a própria Revolução e, portanto, deveriam ser condenados. O fanatismo de Évariste se acentua quando as "virtudes" que considera obrigatórias a todos os cidadãos se 
tornam amarras que impedem a coexistência entre os diferentes. $\mathrm{O}$ triunfo da soberania do povo também significou sua tirania, representados por aqueles que tinham ligação direta com o governo revolucionário.

Após os últimos julgamentos de que participou (que incluíam amigos seus), France nos mostra os últimos momentos de Évariste, que foram também os últimos da República jacobina e de seu líder, Robespierre. Os pensamentos do personagem demonstram mais uma vez quão desumano se tornava na busca da felicidade comum através da salvação da nação. Meditava como se fizesse uma prece 7 , indo além de seu próprio mestre ao pensar que não deveria haver tolerância com aqueles que ameaçavam de qualquer forma a República, todos pagariam por seus crimes contra a nação. Era preciso agir imediatamente pois já eram visíveis as conspirações dentro da própria Convenção contra Robespierre. Évariste considerava-o culpado por não deter os complôs.

Neste momento Évariste sabe que a queda é iminente, a despeito de todo o seu ardor (revolucionário?); sente-se só entre seus compatriotas, e compreende que as pessoas estavam cansadas da Revolução, das mortes, da guilhotina. E assim, não haveria como evitar a queda dos jacobinos. Se sente como um estrangeiro, como estivesse apenas de passagem. Não compartilharia o futuro que estava sendo construído por ele, no seu presente.

Com a proscrição de Robespierre e seus partidários, Évariste também é levado prisão e condenado. Devaneia uma última vez:

- "Morro de forma justa - pensou. - É justo que recebamos esses ultrajes
lançados à República e dos quais deveríamos tê-la defendido. Fomos fracos;
tornamo-nos culpados de indulgência. Traímos a República. Merecemos nosso
destino. O próprio Robespierre, o puro, o santo, pecou por brandura, por
mansuetude; seus erros foram apagados por seu martírio. Como ele, eu traí a
República; ela está perecendo: é justo que eu morra com ela. Poupei sangue: que
meu sangue corra! Que eu pereça! Mereci este destino..." (FRANCE, 2007, p.
227).

7 "Ó terror salutar, ó santo terror! No ano passado, nesta mesma época, tínhamos como defensores vencidos heróicos em farrapos; o solo da pátria estava invadido, dois terços dos departamentos insurretos. Hoje, nossos exércitos bem equipados, bem instruídos, comandados por generais habilidosos, tomam a ofensiva, prontos para levar a liberdade ao mundo. A paz reina em todo o território da República... Ó terror salutar! Ó santo terror! Amável guilhotina! No ano passado, nesta mesma época, a República estava dilacerada em facções; a hidra do federalismo ameaçava devorá-la. Agora, a unidade jacobina estende sobre o império sua força e sua sabedoria..." (FRANCE, 2007, p. 211-212). 
Paris entrou em clima de festa com a queda dos jacobinos. A partir de agora eles eram cunhados de 'sanguinários', 'terroristas', e o seu discurso sobre a virtude do povo, esquecido. As ruas entraram em "uma atmosfera de feriado nacional" (LOOMIS, 1965, p. 380) quando os responsáveis pelo Terror deixaram de existir. Com a queda de Robespierre e o fim do Terror, novas mudanças e um novo curso para a Revolução tomaram caminho, tornando todos os símbolos daquele período sanguinário motivo de escárnio. Agora eram vendidas estampas mostrando Robespierre espremendo um coração dentro de uma taça, ou temas militares, enquanto os bustos de Marat eram destruídos pela cidade. De agora em diante, os franceses tentariam esquecer aquilo que ficou conhecido como Terror.

V.

Anatole France escreveu Les dieux ont soif quando a República já estava estabelecida na França, a partir de 1870, após as experiências revolucionárias e restauradoras do século XIX. Durante todo esse período a Revolução foi amplamente debatida e sua herança postulada pelos novos grupos políticos, especialmente os republicanos. Toda a década revolucionária (1789-1799), desde seu início, suas causas e consequências foram retomadas, e a questão do Terror, essa radicalização, teve de ser explicada ou compreendida por seus estudiosos. Os fundadores da Terceira República que reclamavam a herança revolucionária e buscavam nela uma origem para o novo regime, acabaram de alguma forma suavizando ou reduzindo o papel do Terror em um processo revolucionário que, de forma global, trouxera benefícios em interesse não só ao povo francês. Jean Jaurès, o famoso socialista e amigo de Anatole France, escreveu uma História Socialista da Revolução Francesa legitimando o Terror como única forma de garantir a unidade da Revolução, embora fosse um meio detestável (FURET; OZOUF, 1989, p. 996).

Através da análise de Les dieux ont soif, observamos a postura franciana quanto ao período histórico retratado na obra. A despeito da posição das correntes políticas que justificavam o Terror como um desvio ou um mal necessário no processo revolucionário, France demonstrará em seu romance justamente essa face da Revolução, que não poderia ser explicada apenas pela retórica dos revolucionários. Para a perspectiva humanista de France, os crimes de um regime ou governo que exceda seus poderes e demonstre intolerância e violência, serão indefensáveis - independente da ideologia que as justifique. Dessa forma, não seria possível ao escritor glorificar a Revolução, esquecendo sua face terrorista. Podemos considerar o seu livro como uma 
forma de garantir alguma reflexão em torno desse momento específico, para que fosse lembrado do que são capazes os regimes autoritários.

Por fim, entendemos que a literatura é capaz de produzir e vincular conhecimento sobre o mundo, permitindo um acesso voltado a zonas obscuras da história. Seu alcance seria de proporcionar uma inteligibilidade à experiência humana, algo que toca os limites do conhecimento histórico - já que a literatura ultrapassaria as fronteiras do conhecimento do possível.

\section{Referências}

AGUIAR, Flavio et al. (Org.). Gêneros de fronteira: cruzamentos entre o histórico e o literário. São Paulo: Xamã, 1997.

ALMEIDA, Milene Suzano. Anatole France no divã. Criação \& Crítica, São Paulo, n. 6, p. 84-89, 2011.

ANDERSON, Perry. Trajetos de uma forma literária. Novos Estudos CEBRAP, São Paulo, n. 77, p. 205-220, mar. 2007.

AXELRAD, Jacob. Anatole France: uma vida sem ilusões. São Paulo: Assunção, 1946.

BANCQUART, Marie-Claire. Préface. In: FRANCE, Anatole. Les dieux ont soif. Paris: Gallimard, 1989. p. 7-37.

BANCQUART, Marie-Claire. Anatole France et Paris. Cahiers de 1'Association internationale des études francaises, n. 42, p. 77-91, 1990.

BANCQUART, Marie-Claire. Anatole France. Paris: Julliard, 1994.

BARROS, José D'Assunção. História e Literatura - novas relações para os novos tempos. Contemporâneos, Santo André, n. 6, p. 1-27, mai./out. 2010.

BASTOS, Alcmeno. Introdução ao romance histórico. Rio de Janeiro: EDUERJ, 2007.

BASTOS, Alcmeno. As fontes documentais e os autores de romances históricos (por eles mesmos). Matraga, Rio de Janeiro, v. 19, n. 31, p. 64-79, jul./dez. 2012.

BOSI, Alfredo. Caminhos entre a literatura e a história. Estudos Avançados, São Paulo, v. 19, n. 55, p. 315-334, set./dez. 2005. 
BRAUDEL, Fernand. Anatole France e a História. Revista de História, São Paulo, n. 146, p. 35-45, 2002.

CHARTIER, Roger. Debate: Literatura e História. Topoi, Rio de Janeiro, v. 1, n. 1, p. 197-216, jan./dez. 2000.

COSTA LIMA, Luiz. A ascensão do discurso histórico e suas relações com a literatura. In: $\mathbf{O}$ controle do imaginário: razão e imaginário no Ocidente. São Paulo: Brasiliense, 1984. p. 113-130.

COSTA LIMA, Luiz. História. Ficção. Literatura. São Paulo: Companhia das Letras, 2006.

COSTA LIMA, Luiz. História. Ficção. Literatura. Uma breve apresentação. Eutomia, Recife, ano I, n. 1, p. 167-176, 2008.

DÖBLIN, Alfred. O romance histórico e nós. História: Questões \& Debates, Curitiba, n. 44, p. 13-36, 2006.

DURANT, Will. Anatole France: o homem e sua obra. Rio de Janeiro: Tecnoprint, 1964.

FRAGA, Denise. Um parágrafo de história na literatura francesa: a representação do Caso Dreyfus em L'Île des pingouins, de Anatole France. 2007. Dissertação (Mestrado em Teoria Literária) - Instituto de Biociências, Letras e Ciências Exatas, Universidade Estadual Paulista, São José do Rio Preto, 2007.

FRANCE, Anatole. Les torts de l'histoire. In: La vie littéraire. 2e sér. Paris: Calmann-Lévy, [19--].

FRANCE, Anatole. Os deuses têm sede. Tradução Daniela Jinkings e Cristina Murachco. São Paulo: Boitempo, 2007.

FRANCE, Anatole. Les dieux ont soif. Paris: Gallimard, 1989.

FURET, François; OZOUF, Mona. Dicionário Crítico da Revolução Francesa. Rio de Janeiro: Nova Fronteira, 1989.

FURET, François. Pensando a Revolução Francesa. Rio de Janeiro: Paz e Terra, 1989.

GENGEMBRE, Gérard. Le roman historique: mensonge historique ou vérité romanesque? Études, Paris, Tome 413, p. 367-377, 2010.

GODECHOT, Jacques. A Revolução Francesa: cronologia comentada, 1787-1799. Rio de Janeiro: Nova Fronteira, 1989. 
GUAZZELLI, Cesar Augusto Barcellos. "Fatos que realmente aconteceram?" Considerações sobre história e literatura. In: SILVEIRA; Helder; ABREU, Luciano; MANSAN, Jaime (Org.). História e Ideologia: perspectivas e debates. Passo Fundo: UPF Editora, 2009. p. 369-384.

HARTOG, François. Du côté des écrivains: les temps du roman. In: Croire en l'histoire. Paris: Flammarion, 2013. p. 163-224.

HOBSBAWM, Eric. A Revolução Francesa. In: A Era das Revoluções (1789-1848). São Paulo: Paz e Terra, 2009. p. 97-132.

HUNT, Lynn. Política, cultura e classe na Revolução Francesa. São Paulo: Companhia das Letras, 2007.

JAMESON, Fredric. O romance histórico ainda é possível? Novos Estudos CEBRAP, São Paulo, n. 77, p. 185-203, mar. 2007.

KETTANI, Assia. De l'Histoire à la fiction: les écrivains français et l'affaire Dreyfus. 2010. Tese (Doutorado em Língua, literatura e civilização francesas) - Université Sorbonne Nouvelle - Paris III, Paris, 2010.

KOSELLECK, Reinhart. Aceleración, prognisis y secularización. Valencia: Pre-Textos, 2003.

KOSELLECK, Reinhart. Futuro passado: contribuição à semântica dos tempos históricos. Rio de Janeiro: Contraponto: Ed. Puc-Rio, 2006.

LOOMIS, Stanley. Paris sob o Terror: 1793-1794. Rio de Janeiro: Civilização Brasileira, 1965.

LUKÁCS, György. O romance histórico. São Paulo: Boitempo, 2011.

MAESTRI, Mário. História e romance histórico: fronteiras. Novos Rumos, Marília, ano 17, n. 36, p. 38-44, 2002.

MEDINA, João. Estética e terror: o romance "Os deuses têm sede" de Anatole France. In: COLÓQUIO LITERATURA E HISTÓRIA: PARA UMA PRÁTICA INTERDISCIPLINAR, 1., 2005, Lisboa. Actas. Lisboa: Universidade Aberta, 2005, p. 27-42.

RÉMOND, René. O século XIX: 1815-1914. São Paulo: Cultrix, 1974.

RICOEUR, Paul. A representação historiadora. In: A memória, a história, o esquecimento. Campinas: Ed. da UNICAMP, 2007. p. 247-296.

RICOEUR, Paul. Tempo e narrativa: A tríplice mímesis. In: Tempo e narrativa. São Paulo: Martins Fontes, 2010a. Vol. 1. p. 93-147. 
RICOEUR, Paul. A experiência temporal fictícia. In: Tempo e narrativa. São Paulo: Martins Fontes, 2010b. Vol. 2. p. 173-265.

RICOEUR, Paul. O entrecruzamento da história e da ficção. In: Tempo e narrativa. São Paulo: Martins Fontes, 2010c. Vol. 3. p. 310-328.

RIEDEL, Dirce Côrtes (Org.). Narrativa: ficção e história. Rio de Janeiro: Imago, 1988.

SIMIAND, François. Método histórico e ciência social. Bauru: EDUSC, 2003.

SZABOLCSI, Miklós. Literatura Universal do Século XX: principais correntes. Brasília: Editora UnB, 1990.

TADIÉ, Jean-Yves. Les écrivains et le roman historique au XXe siècle: esthétique et psychologie. Le Débat, Paris, n. 165, p. 136-145, 2011.

VARGAS LLOSA, Mario. La verdad de las mentiras. Buenos Aires: Alfaguara, 2009.

VOVELLE, Michel. A Revolução Francesa 1789-1799. São Paulo: UNESP, 2013.

WINOCK, Michel. O século dos intelectuais. Rio de Janeiro: Bertrand Brasil, 2000.

\footnotetext{
Abstract: The objective of this work is to problematize the representation of the past in the novel Les dieux ont soif (The Gods Are Thirsty, 1912) of the french writer Anatole France (1844-1924). The past is not only the history of the French Revolution and the period of the "Terror" that the novel approach, but which combines the author's present, his trajectory and the socio-cultural and political context of the early twentieth century. The novel proves remarkable capacity of historical representation about the period it seeks to portray, as well as eliciting a discussion about time, a key element of its construction.
}

Keywords: Anatole France. French Revolution. Historical novel. Representation of the past. 